\title{
Kaksi provokatiivista kysymystä rahasta ja politiikasta
}

\author{
Eetu Viren, toimittaja, kumu.info
}

\section{I}

Miksi julkisten menojen suoran keskuspankkirahoituksen kiellosta ja keskuspankkien "itsenäisyydestä", eli alistamisesta finanssimarkkinoiden alaisuuteen parlamentaarisen ohjauksen sijasta, on tullut käytännössä itsestään selvä, yleisen poliittisen mielipiteen hyväksymä tosiseikka? On selvää, että kyse on ainoastaan poliittisesta valinnasta eikä taloustieteellisestä välttämättömyydestä, kuten jälkikeynesiläinen talousteoria on ansiokkaasti osoittanut. Valtion pakko rahoittaa menojaan myymällä velkakirjoja rahoitusmarkkinoille johtaa sekä valtion menojen kasvuun korkomenojen muodossa että kaventaa oleellisesti finanssipoliittista liikkumavaraa. Siitä huolimatta kaikki keskeiset poliittiset puolueet sekä merkittävä osa ihmisistä näyttävät kannattavan tämän ratkaisun ympärille syntynyttä poliittista tasapainoa.

Onko kyse suuresta puhalluksesta, väärästä tietoisuudesta? Onko jälleen kysyttävä, miksi ihmiset taistelevat oman orjuutensa puolesta kuin kyse olisi heidän vapaudestaan, kuten Baruch Spinoza kysyi Teologis-poliittisessa tutkielmassaan (1670)?

Entä jos ihmiset pikemminkin näkivät teollisessa palkkatyössä oman orjuutensa ja finanssimarkkinoiden vapauttamisessa ja pörssikeinottelussa (hieman kuten lottovoitossa, siis ylipäätään "ilmaisessa rahassa") vapauden mahdollisuuden? Yhdysvalloissa reaalipalkkojen mediaanitason kehitys pysähtyi jo vuonna 1973 ja alimmissa palkkaluokissa jo noin viisi vuotta aikaisemmin. Jo tuolloin oli selvää, että sen lisäksi, että palkkatyö vie koko elämän ajan ja tuhoaa ruumiit ja aivot, palkkatyöllä ei edes vaurastu. Niin amerikkalaiset kuin vähitellen muutkin aiemmin etuoikeutettujen länsimaiden asukkaat ovat - jatkuvasti orjan asemassa olleen globaalin Etelän lisäksi - työskennelleet 
ainakin käytännössä enemmän ja tienanneet vähemmän. Yhdysvalloissa erityisesti kouluttamattomien valkoihoisten naisten eliniänodote on laskenut lähes yhtä paljon kuin miesten eliniänodote Venäjällä 1990-luvulla - juuri siivous- ja McDonalds-tyyppisen työn kuormittavuuden takia. Talouskriisin aikana tai myös sitä edeltäneiden 5-10 vuoden aikana työmarkkinoille tullut sukupolvi on myös lukuisten tutkimusten mukaan ensimmäinen, joka uskoo että siitä tulee köyhempi kuin vanhemmistaan.

Kun amerikkalaisten työläisten palkkakehitys pysähtyi jo vuonna 1973, oliko 1970-luvun lopulla lainkaan irrationaalista, että työläiset alkoivat kannattaa finanssoitumista työpaikkojen luomisen sijaan? Keskeisiä keinoja, joilla myös hallinto pyrki sitomaan työntekijöitä finanssimarkkinoiden kohtaloon, olivat asunnon omistamisen helpottaminen ja asuntolainojen saatavuuden parantaminen asuntolainajohdannaisten sääntelyn purkamisen avulla. Kun palkat eivät nousseet, työläinen ajatteli voivansa rikastua asuntonsa arvonnousun avulla, kuten monille 20-30 vuoden ajan kävikin. Finanssimarkkinoiden vapauttamisen nähtiin voivan ruokkia asuntojen hintojen nousua (oli kyse sitten "todellisesta" tai "väliaikaisesta" spekulatiivisesta ilmiöstä). Keynesiläisyydellä oli tarjottavana ainoastaan työpaikkoja, siis lisää työtä ilman vaurastumisen mahdollisuutta.

Asuntolainojen ohella toinen olennainen arkipäivän finanssoitumisen muoto olivat yksityiset eläkesäästöt, joissa amerikkalainen middle class epäilemättä näki keinoin päästä ulos oravanpyörästä: kun eläkesäästöjeni arvo kohoaa pörssissä kuin hiiva - samoin kuin Hollywood-elokuvissa kuvattujen pankkiirien omaisuus - voin edes eläkkeelle päästessäni olla rikas, vaikka palkkani ei nousekaan. Tämän kapitalismin finanssoitumisen eräänlaisen mikrohistorian kirjoittaminen olisi nähdäkseni äärimmäisen keskeistä nykyisten poliittisten muutosten ymmärtämisen kannalta...

Wolfgang Streeckin kirjassa Ostettua aikaa (Streeck 2016), jota toki voi kritikoida monesta näkökulmasta - on yksi kiinnostava käsite ja argumentti, joita en ole löytänyt monestakaan viime vuosikymmenten talouden muutoksia kuvaavasta kirjasta. Streeck pyrkii hahmottamaan syitä tai motiiveja sille, miksi valtion yksityisen rahoituksen pakko on hyväksytty, ja viittaa siihen, että valtion yksityisellä velkaantumisella on myös positiivisia vaikutuksia ainakin tiettyjen yhteiskunnallisten ryhmien kannalta. Nimittäin niiden, jotka omistavat ja saavat tuottoja valtion velkakirjoista. Erityisesti 1970-luvun lopussa ja 
1980-luvun alussa suhteellisen korkean inflaation aikana valtion velkakirjoilla oli myös Suomessa kohtuullisen tärkeä merkitys keskituloisten palkansaajien varallisuuden arvon säilymisen kannalta, koska ne toimivat keinona saada säästöille selkeästi enemmän tuottoa kuin reaalisesti matalakorkoiset käyttötai säästötilit.

Niin sanottu fordistinen hyvinvointivaltio ei myöskään välttämättä aina ollut työläisten kannalta niin edullinen kuin on annettu ymmärtää. Sven Steinmo kuvaa, miten varsinkin Ruotsissa, hyvinvointivaltion ikuisessa mallimaassa, työläiset tosiasiassa maksoivat itse käytännössä kaikki kansankodin kustannukset aina 1970-luvun alkuun asti, ja siksi yritys- ja pääomaveroprosentit olivat myös 1960-luvulla poikkeuksellisen matalia (Steinmo 2013). Tämä näkyy edelleen siinä, että varallisuuserot ovat Ruotsissa erittäin suuret, vaikka tuloerot ovat pienet. Hyvinvointipalvelut rahoitettiin siis palkkatyöstä maksettavista veroista ja maksuista, ja vasta poikkeuksellisen voimakkaiden villien lakkojen jälkeen 1960-70-lukujen vaihteessa, esimerkiksi Kiirunan kaivoksilla, rahoitusvastuuta siirrettiin hieman myös pääoman harteille.

Yhdysvalloissa taas finanssimarkkinoiden vapauttamisen äänekkäimpiin kannattajiin kuului Ralph Naderin johtama ns. kuluttajaliike, joka vaati talletuspankkien korkosäätelyn vapauttamista. Erityisesti 1970-luvulla, kun valtio ja pääoma tietoisesti käyttivät inflaatiota keinona ottaa takaisin kiertokulun alueella tuotannon piirissä tehdyt myönnytykset eli kasvaneet palkankorotukset, työntekijät tajusivat selvästi työllä keräämänsä varallisuuden reaaliarvon jatkuvasti heikkenevän vielä palkkatason nousua nopeammin. Siksi monet alkoivat kannattaa niin yksityisiä eläkerahastoja kuin rahoitusalan vapauttamista säätelystä. Lisäksi juuri tässä historiallisessa tilanteessa Reaganin ja Thatcherin uuden patrimoniaalisen yhteiskuntasopimuksen - emme maksa teille enempää palkkaa, mutta ostakaa velaksi asunto ja rikastukaa sen arvon noustessa - suosio ei ollut lainkaan yllättävää.

Hieman samanlainen tilanne on nykyisin Kiinassa, jossa hallitus ja keskuspankki ovat tarkoituksellisesti painaneet keskituloisten työntekijöiden pankkitalletuksista maksettavat reaalikorot negatiivisiksi, jotta vientiyritykset saavat edullista luottoa. Korkopolitiikan lisäksi valuutan ulkoisen arvon pitäminen matalalla on merkinnyt suoraa tulonsiirtoa kotitalouksilta vientisektorille, kuten Michael Pettis on korostanut (Pettis 2013). Siksi ei olekaan ihme, että jopa yritykset luoda Kiinaan entistä laajempia osakemarkkinoita 
ovat keränneet kannatusta (vaikka hallituksen lietsomat pörssikuplat lopulta ovatkin romahtaneet), koska pankkitilillä säästöjen reaaliarvo vain laskee.

Ehkä työläiset ovatkin täysin rationaalisia haaveillessaan mieluummin rahasta kuin työstä, mieluummin vallan siirtämisestä finanssimarkkinoille kuin "palauttamisesta" valtiolle?

\section{II}

Useimmin siteerattu määritelmä modernille valtiolle on se, että valtio on "legitiimin väkivallan monopoli tietyllä alueella". Modernin valtion tärkein instituutio on siis poliisi. Kuten viimeksi itsenäisyyspäivänä olemme saaneet nähdä, poliisi seisoo rivistönä suojaamassa natsien mielenosoitusta, antaa natsien käyttää mielenosoituksessaan metallisia lipputankoja vaikka on takavarikoinut puukepit vasemmistonuorilta ja niin edelleen. Sivumennen sanoen, tämän päivittely on kummallista siksi, että poliisi on instituutio, joka on perustettu nimenomaan kapitalistien omaisuuden suojelemista varten 1700-luvun lopun Englannissa. Siksi ei ole ihme, jos poliisi keskittää voimansa anarkisteja tai muuta "äärivasemmistoa" vastaan, koska he uhkaavat kapitalistien omaisuutta. Poliisin näkökulmasta natsit uhkaavat ainoastaan ulkomaalaisten tai yhteiskunnan vihollisten fyysistä turvallisuutta, ja eivät siksi ole uhka yleiselle järjestykselle.

Tästä näkökulmasta ei kenties olekaan ihme, että oikeiston vaatimukset valtion vallan rajoittamisesta ja julkisten menojen karsimisesta ovat saaneet kannatusta. Ehkä julkisia menoja - ainakin joiltakin osin - olisi syytäkin karsia. Toki osa valtion instituutioista on, eri yhteiskunnallisten liikkeiden taisteluiden seurauksena saanut aikaan myös muita, prekaarin työntekijän näkökulmasta positiivisempia vaikutuksia. On kuitenkin syytä muistaa, että historiallisesti myös esimerkiksi sosiaaliturvan ja julkisen päivähoidon tarkoitus on ollut ennen kaikkea työvoiman saatavuuden takaaminen, ei toimeentulon takaaminen (mikä näkyy hyvin siinä, että edelleen viimesijaista toimeentuloturvaa, toimeentulotukea voidaan alentaa jopa 40 prosenttia työpaikan vastaanottamisesta tai työvoimapoliittisista toimenpiteistä kieltäytymisen vuoksi).

1960-1970-luvun vaihteen Yhdysvalloissa parjattujen uusliberaalien lisäksi myös esimerkiksi Mustat Pantterit vaativat valtion vallan rajoittamista ja 
pyrkivät ottamaan niin turvallisuudesta kuin toimeentulosta huolehtimisen omiin käsiinsä. Jos valtio ei ole automaattisesti hyvä, minkä olisi toki jo kauan pitänyt olla itsestään selvää, voisiko ollakin niin, että valtion merkittävin "positiivinen" tehtävä alistettujen ryhmien kannalta liittyykin ennen kaikkea mahdollisuuteen luoda rahaa, joka on irrotettu kapitalististen yksityisten liikepankkien tai muiden rahoituslaitosten kontrollista.

Yleensä vasemmiston piirissä rahaa pidetään jollakin tavoin pahana, sen katsotaan turmelevan aitoja ihmisten välisiä suhteita jo pelkästään teknisten ominaisuuksiensa johdosta (ehkä hieman samalla tavalla kuin nuoret humanistit pitävät matematiikkaa, kalkyloivaa ajattelua, kartesiolaisuutta jne. runouden, yhteisön ja aidon ihmisyyden vihollisena). Mutta entä jos nimenomaan muut valtion instituutiot, kuten poliisi, sossu, työkkäri ja koululaitos ovatkin työvoiman alistamisen ja kontrollin instituutioita ja suvereenin valtion ainoa hyvä puoli on se, että se voi luoda rahaa tyhjästä ja antaa sitä työläisille "ilmaiseksi", siis ilman työsuoritusta? Siis luoda rahaa, jonka luomisen eli liikkeelle laskemisen välineet eivät ole minkään erityisen ryhmän hallussa, vaan muodostavat yhteiskunnallisen kentän, jolla esimerkiksi työsuoritusten ja eri hyödykkeiden arvon mittaamisesta voidaan käydä avointa kamppailua.

Raha ei kapitalistisessa yhteiskunnassa ole neutraali ennalta olemassa olevan arvon mitta tai ilmaus, vaan kamppailujen tai valtasuhteiden olemassaolon muoto. (Myös jälkikeynesiläinen teoria on ymmärtääkseni jo pitkään nähnyt esimerkiksi inflaation ennen kaikkea työvoiman ja pääoman välisen valtasuhteen ilmauksena.) Raha on nykyisin yhteiskunnallisen vallan ja voiman yleinen ilmaus, koska kaikki on hankittavissa rahalla (tosiasiassa money can buy me love, koska rakkaudessakin on kyse ennen kaikkea elämän mahdollisuuksista). Raha on virtuaalisuuksien yleinen muoto. Se voi antaa näkyvän mittapuun erilaisille kamppailuille ja toimia rahataloudessa erilaisten yhteiskunnallisten voimien ilmi tulemisen muotona. Esimerkiksi 1970-luvun feministit korostivat vaatiessaan palkkaa kotityöstä, että itse vaatimus on keskeinen keino tuoda näkyväksi naisten ilmaisen kotityön tuottama taloudellinen arvo ja palkkatyön ulkopuolella olevat naiset yhteiskunnallisena subjektina.

Jos kaikki elämän kannalta välttämättömät hyödykkeet täytyy ostaa rahalla, se miten rahaa saa - raatamalla paskaduunissa kapitalistin palveluksessa, itse 'haslaamalla' vai vastikkeettomasti yhteiskunnallisena investointina tuottavaan 
elämään - on kaikkein keskeisin yhteiskunnallinen kysymys. Tämä on jäänyt ymmärtämättä suurelta osalta taloustiedettä, sosiologiaa ja vasemmistolaista poliittista ajattelua. Sen sijaan klassiset itärannikon rap-artistit ovat tajunneet asian hyvin. Jos aika on rahaa, raha on aikaa. Siksi se on valtaa suhteessa ympäristöön ja omaan elämään.

\section{Lähteet}

Pettis, Michael (2013) Avoiding the Fall. China's Economic Restructuring, Carnegie Endowment for International Peace: Washington D.C.

Spinoza, Baruch (1670) Tractatus theologico-politicus.

Steinmo, Sven (2013) Governing as an Engineering Problem: The Political

Economy of Swedish Success. Teoksessa A. Schäfer \& W. Streeck (toim.):

Politics in the Age of Austerity, Polity: Cambridge.

Streeck, Wolfgang (2016) Ostettua aikaa. Vastapaino: Tampere. 